\title{
Pemanfaatan Aplikasi Kahoot! dan Quizizz Sebagai Media Pembelajaran Interaktif Berbasis Gamifikasi
}

\author{
Rahman Abdillah ${ }^{1 *}$, Adhityo Kuncoro' ${ }^{2)}$, Fajar Erlangga ${ }^{3)}$, Vickry Ramdhan ${ }^{4)}$ \\ 1)2)334) Universitas Indraprasta PGRI, Indonesia \\ 1rabdil.bu@gmail.com, ${ }^{2}$ adhityokuncoro@yahoo.com, ${ }^{3}$ erlangga.dawn@gmail.com, \\ ${ }^{4}$ vickry.ramdhann@gmail.com
}

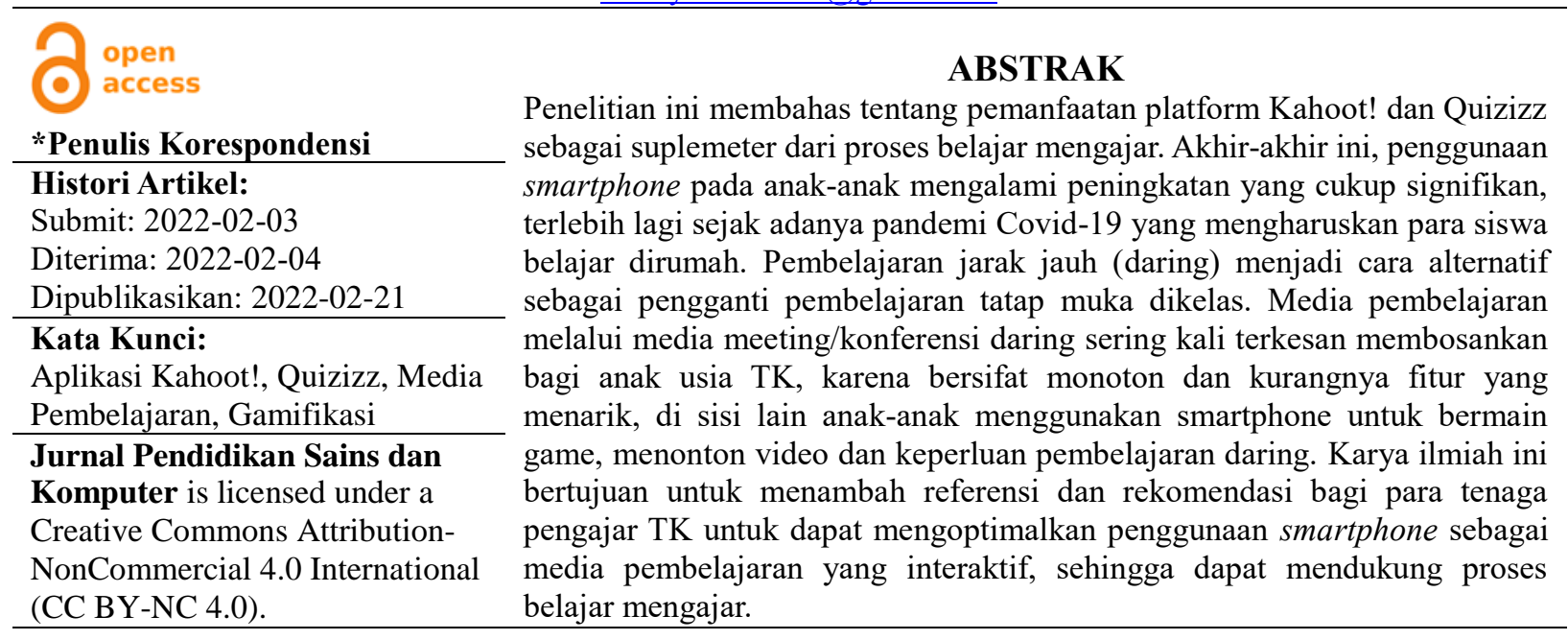

\section{LATAR BELAKANG}

Pada masa-masa terjadinya pandemi Covid-19, berbagai macam aspek kehidupan manusia dituntut untuk melakukan transformasi digital untuk meminimalisir terjadinya pertemuan manusia secara langsung. Berbagai macam aspek mulai dari sosial, ekonomi, pendidikan, hiburan, kesehatan dan berbagai pelayanan administrasi dilakukan secara digital. Beberapa hal yang tidak dapat dilakukan secara digital akan mengalami dampak penurunan yang cukup signifikan, seperti halnya pada bidang pariwisata dan usaha jasa MICE (Meetings, Incentives, Conferencing dan Exhibitions). Seperti halnya pada area-area penyebaran Covid-19 yang biasanya terjadi pada daerah dengan kerumunan banyak orang, seperti pada mall, pusat perbelanjaan, pasar, perkantoran, tempat wisata area-area lembaga pendidikan sebagai tempat bertemunya para siswa, guru, mahasiswa, dosen juga merupakan tempat yang cukup rentan dalam penyebaran Covid19. Para penyelenggara lembaga pendidikan dan perguruan tinggi juga mendapat himbauan dari Kemdikbudristek untuk melakukan pembelajaran secara daring (online), namun beberapa kali aturan juga mengalami evaluasi dengan adanya Pembelajaran Tatap Muka (PTM) terbatas. Kominfo menilai PJJ yang berkepanjangan bisa berdampak besar dan permanen terhadap para pelajar. Dampak yang sangat diantisipasi, diantaranya putus sekolah, penurunan capaian pembelajaran, dan kesehatan mental serta psikis anak-anak. Terjadinya pandemi Covid-19 ini telah menyebabkan learning loss yang sangat signifikan. Johnny G Plate menuturkan, jika dibiarkan secara jangka Panjang, semua ini bisa menjadi risiko yang lebih besar dibandingkan risiko kesehatan (Antara News, 2021).

Berdasarkan Surat Keputusan Bersama (SKB) Empat Menteri mengenai penyelenggaraan pembelajaran dimasa pandemi Covid-19 yang terbit pada tanggal 21 Desember 2021, pemerintah berupaya memulihkan pembelajaran dengan membuka sekolah secara tatap muka di semester genap tahun 2022 secara terbatas, dan tidak semua satuan Pendidikan bisa menggelar PTM penuh (100 persen). Dalam SKB Empat Menteri tersebut, tercantum bahwa satuan pendidikan di wilayah PPKM (Pemberlakuan 


\section{Jurnal Pendidikan Sains dan Komputer}

Pembatasan Kegiatan Masyarakat) level 1 dan 2 bisa melaksanakan PTM dengan jumlah peserta didik 100 persen jika capaian vaksinasi dosis 2 pendidik dan tenaga kependidikan paling sedikit 80 persen. Dengan begitu, sekolah juga bisa menyelenggarakan PTM setiap hari dengan lama belajar paling banyak enam jam pelajaran per hari. Namun jika capaian vaksinasi dosis 2 pendidik dan tenaga kependidikan di wilayah PPKM level 1 dan 2 berada di antara angka 50-80 persen, maka satuan pendidikan di wilayah tersebut hanya diperbolehkan menyelenggarakan PTM terbatas dengan jumlah peserta didik 50 persen dari kapasitas ruang kelas. PTM terbatas di wilayah itu bisa diselenggarakan setiap hari, namun harus dilakukan bergantian sesuai dengan jadwal yang diatur sekolah berdasarkan jumlah siswa dan ketersediaan ruang kelas, dengan lama belajar maksimal enam jam pelajaran per hari (setjen.kemdikbud.go.id, 2022).

Penggunaan teknologi informasi dalam pembelajaran menjadi transformasi penting yang harus dilakukan oleh berbagai tingkat satuan pendidikan. Dampak dari terjadinya pandemi ini adalah terjadinya perubahan proses dan metode belajar siswa (Ginting, et.al, 2021). Ada berbagai macam istilah pembelajaran digital yang digunakan, yaitu Pembelajaran Jarak Jauh (PJJ), dan Hybrid Learning. Berbagai media sosial dan aplikasi juga digunakan untuk mendukung proses belajar mengajar, seperti: Google Classroom, Zoom, Edmodo, Youtube dan lain sebagainya (Kurnia, 2020) \& (Iman, et. Al, 2021) .

\section{STUDI LITERATUR}

Media pembelajaran daring (online) merupakan alat atau perantara pembelajaran yang dilakukan dengan tanpa bertatap muka langsung, namun menggunakan media teknologi internet yang dapat membantu proses belajar mengajar jarak jauh. Adapun pada penelitian ini, penulis membahas platform Kahoot! dan Quizizz dengan jumlah pengguna yang cukup banyak digunakan. Sampai dengan tulisan ini dibuat, setidaknya ada 50juta pengguna yang pernah menggunakan Kahoot! dan setidaknya ada 5 juta pengguna yang pernah menggunakan Quizizz melalui aplikasi android.

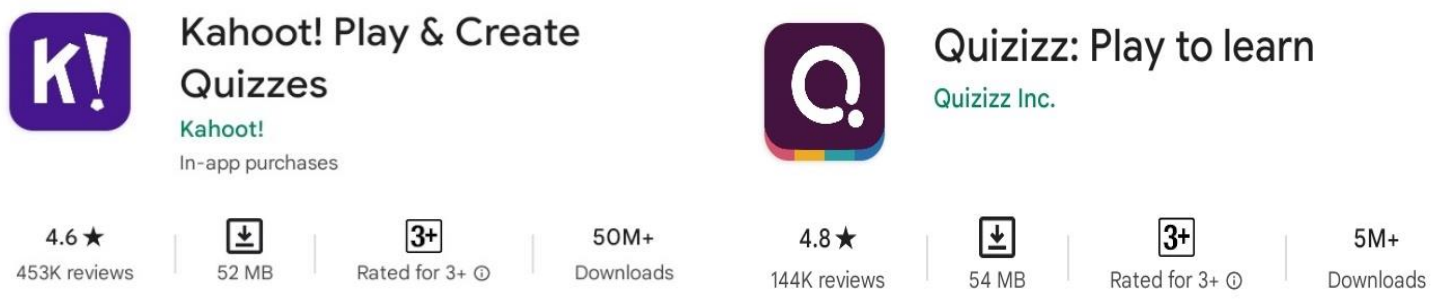

Gambar 1. Perbandingan jumlah pengguna Kahoot! dan Quizizz pada Google Play Store

\section{Kahoot!}

Aplikasi Kahoot! pada dasarnya tersedia sebagai aplikasi pembelajaran yang gratis, namun untuk mendapatkan fitur layanan yang lebih kompleks aplikasi ini juga ada layanan akun berbayar. Platform ini merupakan salah satu platform pembelajaran berbasis gamifikasi. Kahoot! tidak mengkhususkan peruntukannya untuk bidang edukasi (Pratolo \& Lofti, 2021), karena pada dasarnya platform ini bisa digunakan untuk permainan, kuis adu cepat, permainan tebak-tebakan yang mungkin tidak ada aspek edukasinya. Namun pada implementasinya, user (pengguna) juga bisa menggunakan untuk media pembelajaran (Mada \& Anharudin, 2019). Hal ini memungkinkan user sebagai pendidik untuk membuat game berbentuk kuis, survey, dan beberapa hal lainnya yang berupa tanya jawab secara interaktif atau adu 


\section{Jurnal Pendidikan Sains dan Komputer}

cepat seperti halnya dalam kelas tatap muka langsung (Iman, et.al, 2021). Namun kelemahan dari platform ini, tidak terdapat fitur menampilkan file powerpoint atau materi dalam bentuk pdf, ataupun fitur video dikarenakan memang pada awalnya platform ini tidak didesain seperti kelas online, seminar atau dalam bentuk konferensi (Licorish, et.al, 2018) \& (Hidayat, et.al, 2020).

Kahoot! memiliki fitur yang bagus yaitu data hasil analisis deskriptif dari terjadinya sesi soal tanya jawab dapat diektraksi, dan disimpan untuk diolah dikemudian hari. Untuk menggunakan platform ini, user dapat masuk ke web Kahoot! (http://getkahoot.com). Setelah memiliki akun Kahoot! (Syach, 2021), user dapat membuat pertanyaan dengan fitur-fitur yang tersedia. Kahoot! menyediakan beragam fitur video, gambar, suara sebagai template gratis, atau ada juga fitur lain yang bisa diimport namun beberapa fitur yang lebih menarik dan lengkap biasanya didapat melalui akun berbayar. Setelah soal selesai dibuat, user akan mendapatkan kode unik sebagai identifikasi yang digunakan oleh seluruh member untuk masuk ke room (ruang) permainan. Siswa dapat mengakses Kahoot! melalui smartphone android, ios dan pc dengan mengakses www.kahoot.it. Setelah masuk ke web tersebut, siswa harus memasukkan kode unik dan memasukkan nama masing-masing. Setelah permainan dimulai, para siswa akan mendapat score secara langsung dari jawaban yang benar, serta penilaian dari kecepatan siswa dalam menjawab pertanyaan. Dengan adanya skema kompetisi antar siswa dan cara penilaian kuis Kahoot! seperti ini, berdasarkan penelitian sebelumnya, para siswa akan mendapatkan motivasi belajar yang lebih baik (Henukh, 2020).

Sebagai bagian dari aktifitas pembelajaran, platform kahoot! telah menjadi alternatif pembelajaran bagi para tenaga pengajar untuk meningkatkan partisipasi siswa dalam pembelajaran (Hidayat, et.al, 2020). Platform Kahoot! terdiri dari dua domain website, yaitu: kahoot.it dan kahoot.com. Website kahoot.com adalah website utama dari platform Kahoot!. Jika user hanya ingin bermain, user sebagai pengguna permainan user diarahkan untuk menggunakan kahoot.it, sedangkan user (pengguna) sebagai admin atau host permainan, kahoot akan mengarahkan untuk menggunakan kahoot.com.

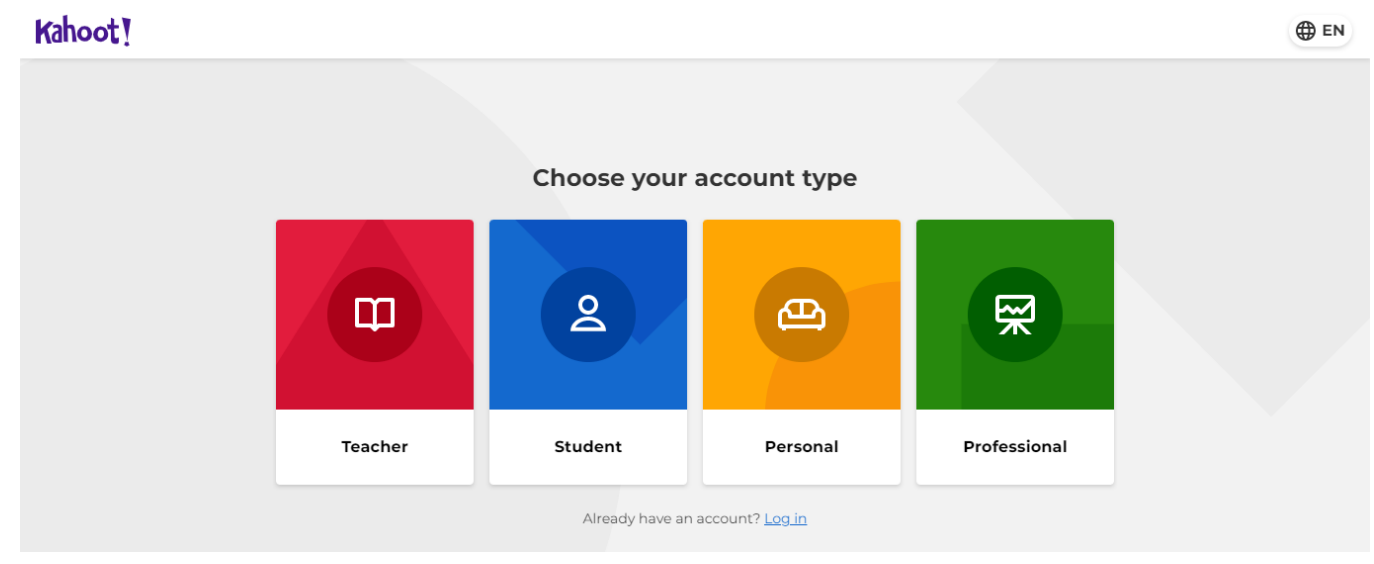

Gambar 2. Tampilan awal log in aplikasi Kahoot!

Gambar diatas adalah tampilan awal setelah login menggunakan akun gmail, namun jika menggunakan aplikasi Kahoot! sebagai peserta permainan tidak memerlukan log in. Setelah berhasil log in, user akan diarahkan untuk menggunakan template pertanyaan yang sudah ada di aplikasi Kahoot!. Pada gambar 2, dapat kita lihat tampilan dashboard Kahoot!. Kita bisa membuat pertanyaan dalam bentuk kuis pilihan ganda, menjawab pertanyaan benar atau salah, polling, puzzle, dengan fitur gambar suara video dan beberapa fitur lainnya. 


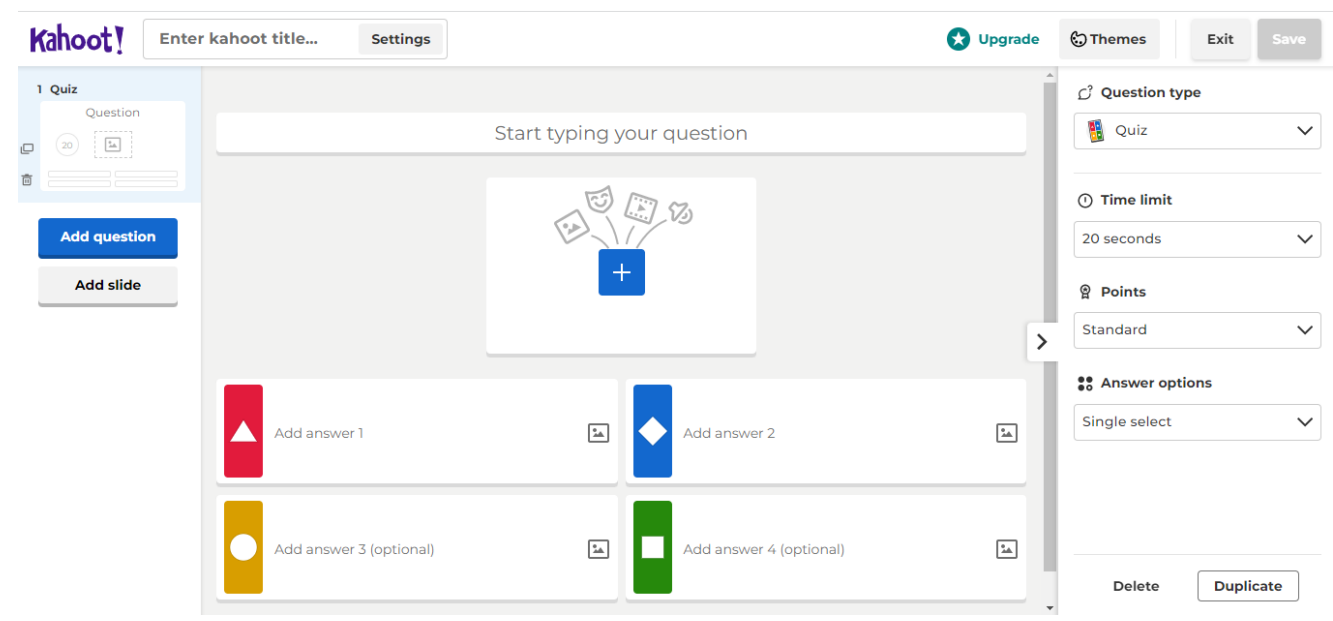

Gambar 3. Tampilan Dashboard Kahoot!

Fleksibilitas platform Kahoot! yang dapat memasukkan fitur berupa gambar, video, suara ke dalam kuis untuk menambah variasi bagi peserta permainan dapat membangkitkan kesan yang menarik dan interaktif bagi penggunannya. Selain itu, adanya kuis secara realtime perlu dukungan koneksi internet yang stabil, walaupun tidak menggunakan kuota yang besar dibandingkan dengan online meeting seperti zoom atau google meet, namun kecepatan koneksi internet menjadi salah satu aspek yang penting pada saat menggunakan Kahoot!.

\section{Quizizz}

Platform asesmen digital yang lain yang cukup menarik untuk digunakan adalah Quizizz. Platform ini hampir sama dengan Kahoot! yaitu platform yang digunakan untuk merancang kuis, tes, polling, survey atau uji diagnostik yang dapat dipisahkan dari proses belajar mengajar utama atau bersifat supplementer (Salsabila, et. Al, 2020). Quizizz dalam implementasinya cukup mudah digunakan karena sudah ada template dasar yang dapat digunakan langsung. Template permainan, pertanyaan atau kuis ada yang tersedia secara gratis, namun ada juga fitur layanan yang berbayar. Tes interaktif yang terdapat dalam platform Quizizz tersedia bermacam-macam bentuk pertanyaan, seperti pilihan ganda, jawaban pertanyaan, pilihan benar dan salah.

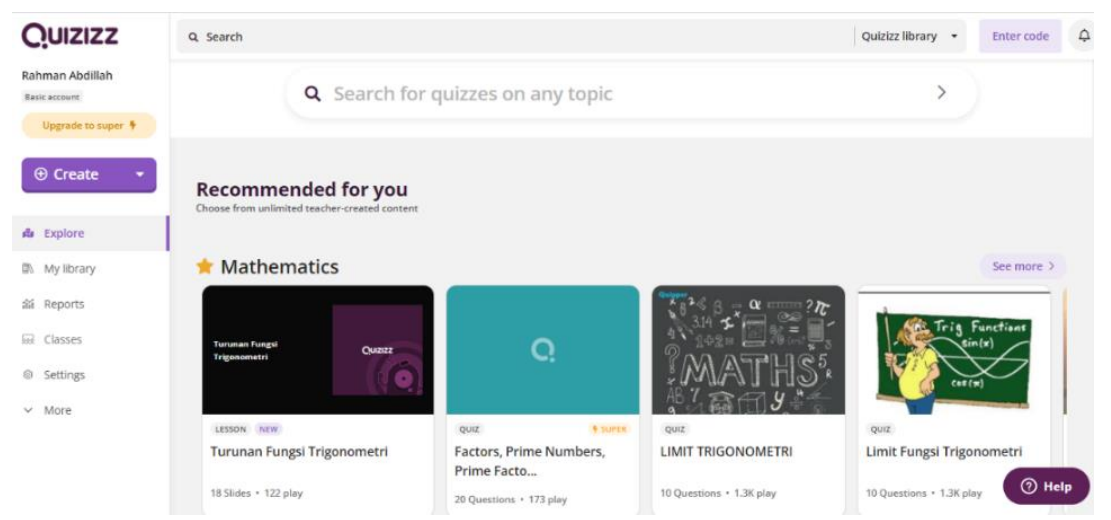

Gambar 4. Tampilan awal (dashboard) Quizizz 


\section{Jurnal Pendidikan Sains dan Komputer}

Platform Quizizz merupakan sebuat platform web based yang dapat digunakan untuk media pembelajaran digital dimana user (pengguna) dapat berinteraksi dengan sesame pengguna lain dan menjadikan suasana belajar yang interaktif (Risan, 2021). Sebenarnya dari pihak developer program Quizizz tidak ada statement secara mengkhususkan peruntukan platform ini untuk alat bantu belajar, namun dalam implementasinya banyak digunakan untuk mendukung penyampaian materi bahan ajar di kelas (Swarniti, 2021). Kelebihan Quizizz dibandingkan dengan platform media interaktif lainnya adalah adanya karakteristik meme, avatar, tema kuis dan adanya iringan instrument musik sehingga lebih meningkatkan motivasi para penggunanya (Aswir, 2020) \& (Bicen, 2018). Dalam platform ini, pelaksanaan kuis dilakukan secara realtime dan pengguna dapat langsung melihat peringkat pengguna dibandingkan dengan pengguna lain.

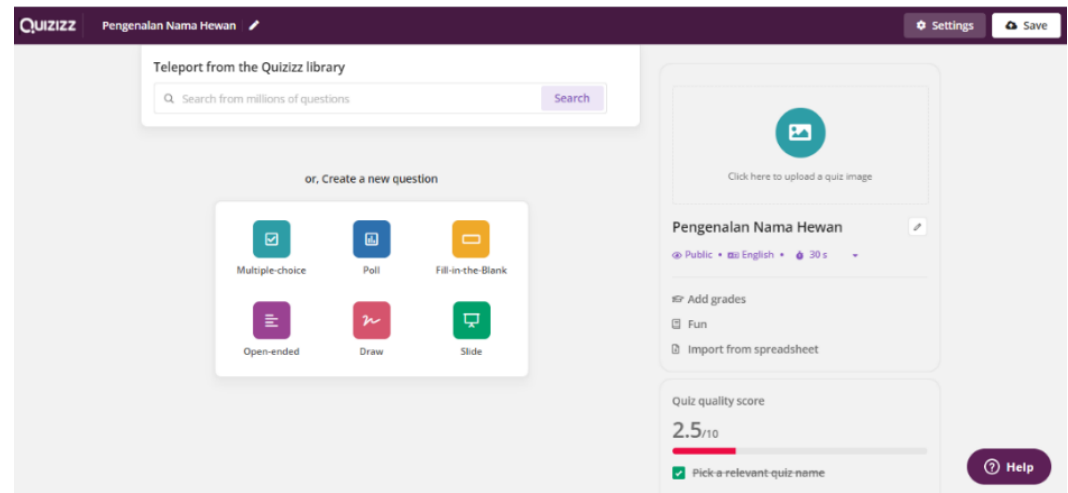

Gambar 5. Tampilan awal Quizizz untuk desain pertanyaan kuis

Dalam penelitian yang dilakukan oleh Agus Suharsono bahwa kekurangan utama dari pengguna adalah koneksi internet yang stabil (Suharsono, 2018). Kekurangan selanjutnya adalah jika digunakan pada smartphone, tampilan layar mudah tertutup karena layar lebih sensitif. Kekurangan lainnya yaitu terlalu banyak iklan (ads) dari google, untuk berpindah soal perlu beberapa langkah yang agak rumit, dan avatar profil tidak bisa diganti. Namun sebagian besar responden $(81 \%)$ berpendapat bahwa Quizizz dapat digunakan untuk menyampaikan materi sesuai dengan tujuan modul/bahan ajar. Dari sudut pandang staff pengajar, menyatakan penggunaan Quizizz sudah cukup baik dan user friendly namun sebaiknya sebelum menggunakan aplikasi ini para guru dan staf pengajar perlu mempersiapkan materi dan soal terlebih dahulu dengan matang.

\section{Gamifikasi}

Gamifikasi adalah suatu proses dimana konsep-konsep umum yang terdapat dalam permainan diintegrasikan kedalam pekerjaan manusia didunia nyata disertai adanya interaksi sosial dengan orangorang yang sebenarnya (Abdillah, 2021) \& (Henukh, 2020). Konsep permainan (game) yang menarik seringkali membuat seseorang cenderung untuk menggunakan permainan secara terus menerus atau bahkan bisa dikategorikan dalam arti kecanduan. Para pengembang game sudah mendesain sedemikian rupa sehingga game akan terus menerus dimainkan oleh para user (pengguna) dengan berbagai fitur tantangan, bonus, interaksi sosial, disertai grafis animasi dan musik yang menarik (Rajendran \& Shah, 2020). Gamifikasi disadur dari kosakata game (permainan) namun sejatinya gamifikasi sama sekali tidak berhubungan dengan aplikasi game yang terdapat pada perangkat lunak. Gamifikasi lebih diartikan sebagai suatu konsep atau metode dimana seseorang dapat terus menerus terikat kepada sesuatu hal yang tanpa 


\section{Jurnal Pendidikan Sains dan Komputer}

disadari namun menjadikan sebuah kebiasaan tersendiri untuk kembali menggunakan suatu platform lingkungan tertentu.

\section{METODE}

Metode penelitian yang digunakan adalah metode deskriptif kualitatif. Peneliti memanfaatkan data kualitatif kemudian dijabarkan secara deskriptif. Hal ini dilakukan peneliti untuk menganalisis keadaan yang terjadi pada tempat penelitian. Dalam penelitian ini peneliti akan menganalisis data kualitatif yang kemudian akan dideskripsikan untuk mendapatkan gambaran secara rinci mengenai beberapa pendapat para guru dan staf pengajar dalam proses penggunaan platform Kahoot! dan Quizizz. Data dan informasi didapatkan dari interview yang dilakukan kepada para guru dan staff pengajar. Metode dalam penelitian ini memfokuskan pada penguraian cara-cara penggunaan aplikasi Kahoot! dan Quizizz kepada para guru dan staff pengajar di Guru TK Gugus Cempaka Lili yang berjumlah 35 orang. Gugus TK Cempaka Lili adalah suatu perkumpulan komunitas guru pengajar TK yang ada di Gang Cempaka dan Gang Lili, Lenteng Agung, Jakarta Selatan.

Pertama, tim peneliti melakukan sosialisasi terlebih dahulu kepada responden dengan menggunakan platform zoom mengenai aplikasi Kahoot! dan Quizizz secara umum dalam bentuk file powerpoint. Kemudian, tim peneliti melakukan demo program secara realtime aplikasi Kahoot! dan Quizizz dan dilanjutkan dengan sesi tanya jawab. Selama sesi berlangsung, dimulai dari sesi sosialisasi, demo aplikasi, tanya jawab sampai dengan pendataan interview, aplikasi zoom tetap dalam posisi merekam. Tahapan pada penelitian ini yaitu dengan presentasi materi, demo aplikasi, tanya jawab, observasi serta wawancara kepada masing-masing responden tentang komentar dan kesan selama menggunakan aplikasi Kahoot! dan Quizizz.

\section{HASIL}

Adapun hasil dari karya ilmiah ini didapat dari beberapa tahapan proses penulisan karya ilmiah ini adalah sebagai berikut: observasi awal, pemaparan materi tentang platform Kahoot! dan Quizizz secara umum, demo aplikasi Kahoot! dan Quizizz serta pengumpulan data dan informasi (observasi lanjutan). Pada bagian hasil ini membahas observasi awal dan proses pemaparan materi sampai dengan demo aplikasi Quizizz dan Kahoot!, sedangkan bagian observasi lanjutan akan dijelaskan pada bagian pembahasan.

\section{Observasi}

Berdasarkan hasil observasi yang dilakukan penulis terhadap para guru di TK Gugus CempakaLili, selama pandemi Covid-19 pembelajaran dilakukan melalui media Whatsapp dengan melakukan voice call dan video call, dan juga rekaman video tentang kegiatan anak dirumah, kemudian dikirimkan melalui Whatsapp. Observasi ini dilakukan dengan menggunakan media zoom meeting. Metode pemberian materi lainnya dilakukan dengan mengirimkan link video youtube kepada Whatsapp Group untuk dipelajari oleh para siswa, biasanya materi berisi tentang pengenalan huruf, nama-nama hewan, nama-nama benda, dan lain sebagainya. Setiap satu bulan sekali, dengan tetap mematuhi protokol kesehatan, orang tua siswa datang ke sekolah untuk mengumpulkan tugas, evaluasi dan pembayaran spp sekolah. Pembelajaran dengan menggunakan metode daring seperti ini cukup efektif, namun kurang interaktif dikarenakan tidak adanya interaksi dengan teman sebaya seperti yang terjadi di kelas secara offline. Kesiapan guru dalam memberikan materi juga perlu menjadi perhatian, bahwa tidak semua guru bisa memberikan pembelajaran materi secara daring. Adanya Rencana Pembelajaran Semester (RPS) yang sebelumnya tercatat dalam panduan 
pengajaran, selanjutnya harus dikembangkan oleh para guru tentang media penyampaian materi pembelajaran. Penggunaan Whatsapp para guru sehari-hari yang biasanya hanya digunakan untuk menulis pesan (chat), dirubah untuk media pembelajaran sehingga perlu beberapa saat bagi para guru untuk adaptasi.

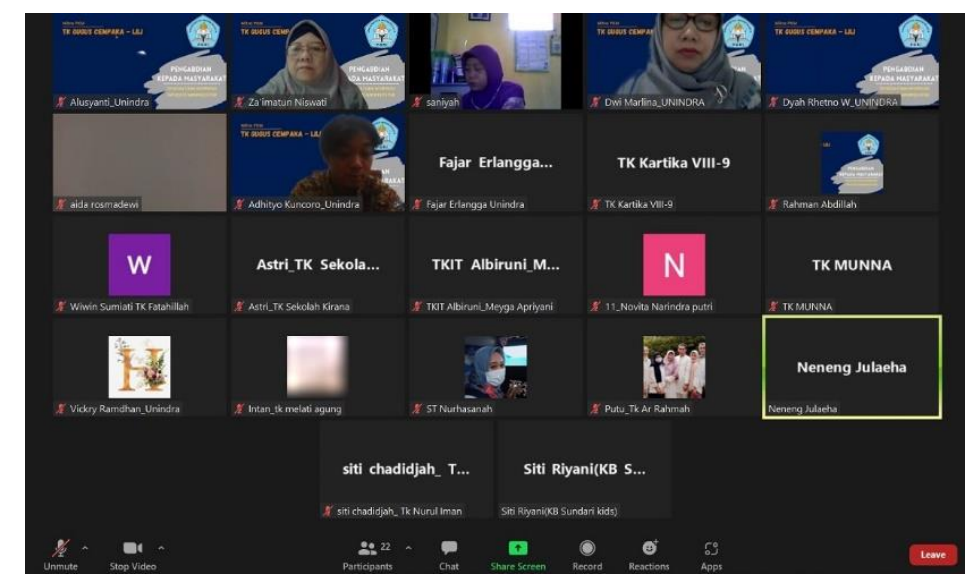

Gambar 6. Sesi Observasi responden melalui zoom meeting

Dalam implementasi metode pembelajaran daring ini tidak semua siswa aktif mengikuti tahapan belajar, mengerjakan dan mengumpulkan tugas. Ketersediaan dan kesiapan media komunikasi internet menjadi hal yang sangat penting dalam pembelajaran daring. Para guru menemukan ada beberapa orang tua siswa yang tidak memiliki smartphone ataupun ada yang memiliki smartphone namun tidak terinstall aplikasi Whatsapp didalamnya. Penyampaian materi dari guru kepada siswa tersebut dilakukan dengan cara menanyakan ke tetangga (orang tua siswa) yang memiliki siswa bersekolah di TK yang sama. Sehingga, berbagai kendala pembelajaran daring ini menyebabkan adanya respon negatif dari beberapa orang tua siswa yang tetap menginginkan sekolah secara tatap muka. Dalam hal ini, pemberian komentar negatif ditujukan kepada guru pengajar, walaupun sebenarnya sistem pengajarannya yang memang diarahkan untuk diadakan secara daring di tengah-tengah kondisi pandemi Covid-19. Jika diambil kesimpulan dari kendala-kendala yang terjadi di pihak guru dan orang tua siswa adalah kendala kesiapan fasilitas pembelajaran daring, yakni: kualitas smartphone (aplikasi Whatsapp), kuota internet dan kesiapan materi bahan ajar dari para guru. Penulis juga tidak menemukan adanya media aplikasi lain selain Whatsapp yang digunakan sebagai media pembelajaran, seperti pada umumnya yang terjadi di jenjang sekolah dasar, seperti penggunaan: Zoom, Google Classroom, Google Meet, dan lain sebagainya. Keterbatasan kompetensi orang tua siswa dalam hal teknologi menjadi kendala yang cukup signifikan. Penulis tidak melakukan observasi kepada para orang tua siswa secara langsung dikarenakan penulis memperhatikan peraturan pemerintah dan kondisi lingkungan yang masih dalam masa pandemi. 


\section{Jurnal Pendidikan Sains dan Komputer}

\section{Pemaparan Materi dan Demo Aplikasi}
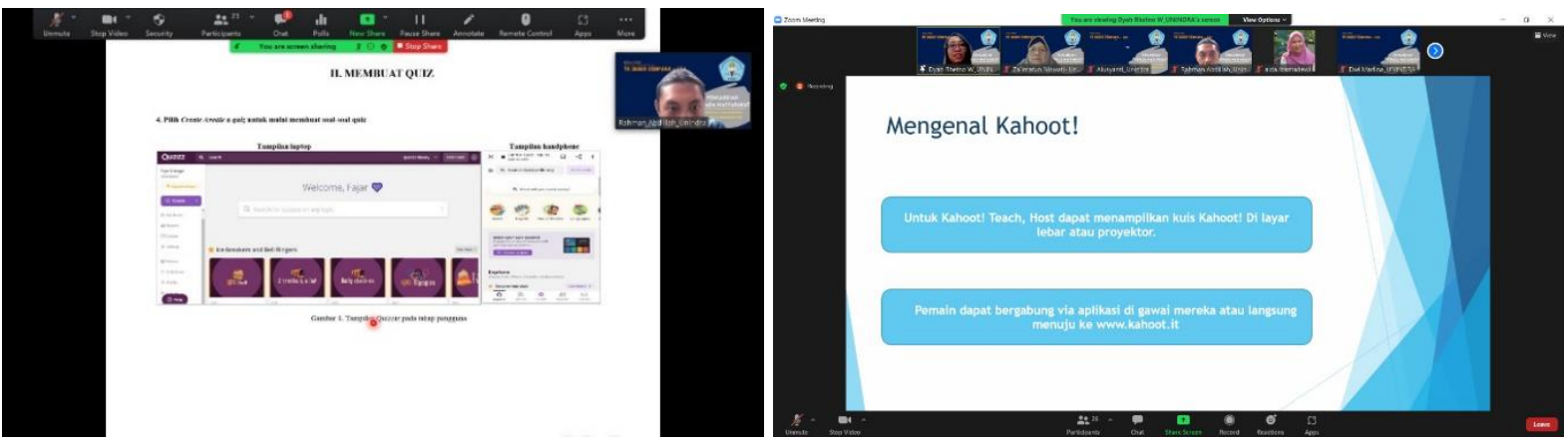

Gambar 7. Pemaparan Materi aplikasi Kahoot! dan Quizizz

Penulis memaparkan materi kepada 35 responden yang keseluruhannya adalah para guru staf pengajar di Gugus TK Cempaka-Lili. Materi yang disampaikan tim penulis adalah pengenalan dan penggunaan aplikasi quizizz dan kahoot!. Materi yang disampaikan dalam bentuk materi powerpoint dan berupa tutorial demo penggunaan aplikasi Quizizz dan Kahoot! secara langsung. Materi tutorial menjelaskan fitur-fitur, tools yang bisa digunakan, termasuk juga bagaimana mengintegrasikan video, gambar dan file suara kedalam aplikasi tersebut. Penulis memberikan penjelasan tentang fitur-fitur yang dapat digunakan namun tidak berbayar. Jika ingin menggunakan fitur yang lebih baik dan bagus, user (pengguna) dapat menggunakan layanan berbayar yang terdapat pada Quizizz dan Kahoot!. Untuk menggunakan fitur yang bagus namun tidak berbayar, penulis memberikan tips tentang bagaimana mengunduh file video, suara dan gambar yang bagus sebagai file masukan pada Quizizz dan Kahoot!. Sehingga user (pengguna) walaupun menggunakan fitur yang tidak berbayar, tetap dapat menggunakan aplikasi tersebut secara interaktif. Sesi terakhir dari pemaparan materi, penulis meminta kepada seluruh responden untuk mengikuti quiz interaktif yang sudah disiapkan sebelumnya. Para guru diminta memasukkan kode khusus untuk secara bersama memulai permainan secara realtime pada link https://quizizz.com/join.

Game PIN, Start

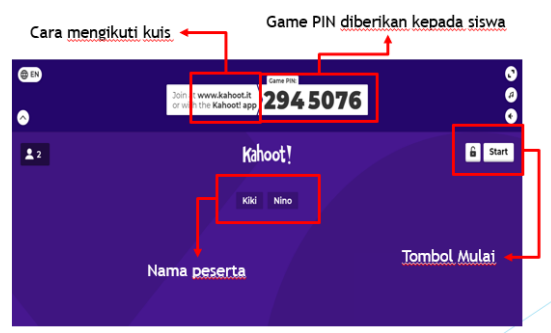

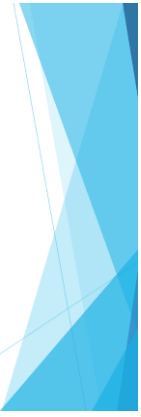

Laporan

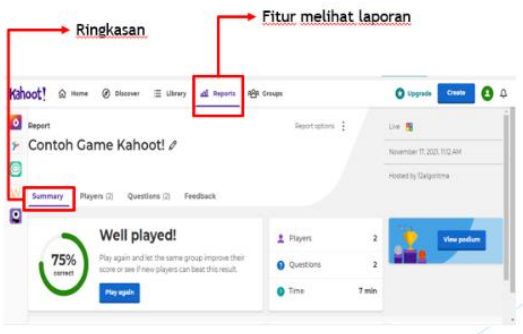

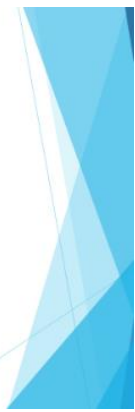

Gambar 8. Tutorial untuk mulai permainan dan menggunakan fitur laporan

Jenis permainan yang dimainkan oleh para guru adalah bertemakan tebak nama hewan, berupa soal pilihan ganda yang menampilkan gambar, suara dan potongan video singkat dari hewan yang dimaksud. Permainan dibuat mudah dijawab, karena nantinya para siswa TK yang akan menggunakan permaian ini. Setelah para guru mencoba bermain permainan secara langsung (realtime), penulis menampilkan dashboard quizizz yang berisikan hasil yang mendapatkan nilai tertinggi dalam bentuk rangking. Diakhir sesi 


\section{Jurnal Pendidikan Sains dan Komputer}

pemaparan materi, penulis menjelaskan cara mengunduh laporan untuk dapat dianalisis lebih lanjut. Laporan ini bisa diunduh dalam bentuk file pdf ataupun Microsoft excel. Para guru juga aktif memberikan saran dan masukan terkait evaluasi dari permainan yang sudah dicoba secara langsung. Penggunaan beberapa fitur untuk dapat diitegrasikan kedalam soal permainan merupakan hal yang baru bagi para guru (user), namun sensasi permainan melalui aplikasi ini sangat interaktif dan bisa membangkitkan kompetisi antar siswa.

\section{PEMBAHASAN}

Pada masa terjadinya pandemi Covid-19 pembelajaran daring dinilai cukup efektif dilaksanakan dengan mengingat penyebaran virus yang masih cukup tinggi. Anak-anak sebagai usia yang cukup rentan dalam terkena dampak penyakit virus namun anak-anak juga tetap harus mendapatkan haknya untuk mendapatkan pendidikan yang layak. Terjadinya learning loss yakni kurang optimalnya transfer ilmu pengetahuan dari guru kepada siswa hendaknya dapat diatasi dengan berbagai cara, termasuk melalui media digital. Namun terkadang para guru yang sudah mempersiapkan materi bahan ajar dengan baik, tidak dapat melakukan transfer pelajaran dikarenakan kurang optimalnya penggunaan media teknologi. Kesiapan materi dan tingkat kompetensi penguasaan teknologi para guru menjadi hal yang utama terjadinya pembelajaran jarak jauh. Perencanaan pembelajaran yang baik perlu mendapat perhatian dan masukan dari pemerintah, praktisi pendidikan dan para pelaku teknologi, sehingga proses pembelajaran bisa berlangsung lebih terstruktur dan sistematis. Berbagai kendala dari implementasi teknologi hendaknya perlu pemikiran dan penyelesaian dari beberapa pihak dan bidang kajian keilmuan. Pemaparan materi yang disampaikan tim penulis kepada para responden di TK Gugus Cempaka-Lili disambut dengan cukup antusias.

\section{KESIMPULAN}

Pada masa pandemi Covid-19 sistem belajar mengajar harus tetap berlangsung. Pada jenjang anak usia pendidikan anak usia dini (PAUD), berbagai macam media teknologi dapat dioptimalkan tidak hanya untuk kebutuhan hiburan dan permainan, namun juga dapat digunakan untuk kebutuhan pembelajaran yang interaktif. Berdasarkan penjelasan diatas, dapat disimpulkan bahwa penggunaan aplikasi quizizz dan kahoot secara umum dapat memberikan dampak positif dalam proses pembelajaran pada jenjang pendidikan anak usia dini (PAUD). Pembelajaran dengan materi pengenalan nama hewan kepada siswa didik dapat lebih efektif dikarenakan adanya fitur dalam menampilkan video dan suara hewan. Sebagian besar guru dan para staff pengurus TK sudah mengenal aplikasi quizizz dan kahoot dan sepakat bahwa media pembelajaran ini cukup menarik. Indikator penguasaan materi hasil dari pembelajaran, yakni para guru ditanyakan secara langsung terhadap ketertarikan para siswa tentang pembelajaran dengan menggunakan Kahoot! atau Quizizz. Dalam penelitian ini, data dan informasi tidak secara langsung dihimpun dari siswa, namun data dan informasi dihimpun dari para guru dan staf pengajar TK. Ada beberapa indikator penilaian yang digunakan dalam penelitian ini, yaitu: indikator keaktifan, indikator motivasi, indikator kepuasan, indikator penguasaan materi dan indikator kemudahan (Swarniti, 2021).

\section{REFERENSI}

Abdillah, R. \& Kurniawan, I. (2021). Tinjauan Analisis Aplikasi Pembelajaran Perangkat Lunak Dari Sudut Pandang Gamifikasi. Indonesian Journal of Education and Humanity, vol. 1, no. 1, pp. 42-48, [Online]. Available: http://ijoehm.rcipublisher.org/index.php/ijoehm/article/view/6. 


\section{Jurnal Pendidikan Sains dan Komputer}

Antara News. (2021). PTM terbatas di DKI dengan kapasitas hingga 100 persen mulai Senin. [Online]. https://www.antaranews.com/berita/2619745/ptm-terbatas-di-dki-dengan-kapasitas-hingga-100persen-mulai-senin.

Aswir, A et al. (2020). Pelatihan Digital Assessment berbasis Kahoot dan Quizizz untuk Guru-Guru Sekolah Dasar Lab School FIP UMJ. Prosiding Seminar Nasional Pengabdian Masyarakat LPPM $U M J$, pp. 1-9, [Online]. Available: https://jurnal.umj.ac.id/index.php/semnaskat/article/view/9171.

Bicen, H \& Kocakoyun, S. (2018). Perceptions of students for gamification approach: Kahoot as a case study. International Journal of Emerging Technologies in Learning, vol. 13, no. 2, pp. 72-93, doi: 10.3991/ijet.v13i02.7467.

Ginting, J. M, Mahfudin, R .K., Yong, V., Aflizar, M., (2021). Pelatihan Penggunaan Aplikasi Quizizz Dan Kahoot Serta Penyuluhan Vaksinasi Covid-19. Prosiding National Conference for Community Service Project, vol. 3, no. 1, pp. 312-316. [Online]. Available: https://journal.uib.ac.id/index.php/nacospro/article/view/5950.

Henukh, A \& Guntara, Y. (2020). Analyzing the response of learners to use kahoot as gamification of learning physics, Gravity:Jurnal Ilmu Penelitian dan Pembelajaran Fisika, vol. 6, no. 1, pp. 72-76, doi: 10.30870/gravity.v6i1.7108.

Hidayat, F. M., et al. (2020). the Application of Kahoot! in Quiz As a Learning Media for English Literature Semiotic Material for Game-Based Tests. Prosiding Sintesa no. November 2020, pp. 1-10.

Iman, N., Ramli, M., \& Saridewi, N. (2021). Kahoot as an Assessment Tools: Students' Perception of Game-based Learning Platform, Jurnal Penelitian dan Pembelajaran IPA, vol. 7, no. 2, p. 245, doi: 10.30870/jppi.v7i2.8304.

Kurnia, M., Rahmawati, M., \& Fitriyana, W. (2020). English Ideas: Journal of English Language Education Vol. 1(1) October 2020 Copyright (C) 2020 English Ideas, vol. 1, no. October, pp. 28-39.

Licorish, S. A, Owen, H. E., Daniel, B., \& George, J. L., (2018). Students' perception of Kahoot!'s influence on teaching and learning, Research and Practice in Technology Enhanced Learning, vol. 13, no. 1, doi: 10.1186/s41039-018-0078-8.

Mada, R. D., \& Anharudin. (2019). How Online Learning Evaluation (Kahoot) Affecting Students' Achievement and Motivation (Case Study on it Students). International Journal Education and Vocational Studies, vol. 1, no. 5, pp. 422-427, doi: 10.29103/ijevs.v1i5.1494.

Pratolo, B. W., \& Lofti, T. M., (2021). Students' Perceptions Toward The Use of Kahoot! Online Game for Learning English, pp. 276-284, [Online]. Available: https://ethicallingua.org/25409190/article/view/250.

Rajendran, T. A/L., \& Mohd Shah, D. P., (2020). Students perception on Gamification: The use of Kahoot, International Journal of Scientific and Research Publications, vol. 10, no. 05, pp. 773-783, doi: 10.29322/ijsrp.10.05.2020.p10190.

Risan, R. (2021). Identifying the Use of Quizzes for Students During Online Learning. JOEPALLT:Journal of English Pedagogy. Linguistics, Literature, and Teaching, vol. 9, no. 2, pp. 52-63, doi: 10.35194/jj.v9i2.1782. 
Salsabila, U. H., Habiba, I. S., Amanah, I. L., Istiqomah, N. A., \& Difany, S. (2020). Pemanfaatan Aplikasi Quizizz Sebagai Media Pembelajaran Ditengah Pandemi Pada Siswa SMA. Jurnal Ilmu Terapan Universitas Jambi|JIITUJ|, vol. 4, no. 2, pp. 163-173, doi: 10.22437/jiituj.v4i2.11605.

Sekretariat Jenderal Kementerian Pendidikan dan Kebudayaan. (2022). Terbitkan Surat Edaran, Kemendikbudristek setujui PTM Terbatas 50 persen di wilayah PPKM Level 2. Februari 2022, setjen.kemdikbud.go.id.

Suharsono, A \& Budiarto, M.T. (2018). Penggunaan Quizizz Sebagai Media Pembelajaran Bagi Generasi Milenial, pp. 1-7.

Swarniti, N. W., (2021). Efektivitas Penggunaan Aplikasi Quizizz Dalam Proses Pembelajaran Bahasa Inggris Bagi Mahasiswa. Seminar Nasional Teknologi Pembelajaran, pp. 133-144.

Syach, M. F. (2021). Kahoot quiz: interactive media in knowing the increase in understanding of the numerical method of oceanographic physics based on Matlab programming, Gravity: Jurnal Ilmu Penelitian dan Pembelajaran Fisika, vol. 7, no. 1, pp. 19-26, doi: 10.30870/gravity.v7i1.9673.

Yulita, I. N. \& Rizka, Y. (2021). Teachers Understanding about Interesting Online Learning Media, REKA ELKOMIKA Jurnal Pengabdian. Kepada Masyarakat, vol. 2, no. 1, pp. 11-18, doi: 10.26760/rekaelkomika.v2i1.11-18. 